\title{
The Effects of HES 130/0.4 Application on Erythrocyte Deformability in Ureteral Obstructed Rats
}

\author{
Üreter Obstrüksiyonu Oluşturulan Ratlarda HES 130/0.4'ün Eritrosit Deformabilitesi Üzerine Etkileri
}

Işın Güneş ${ }^{1}$, Ayşegül Küçük ${ }^{2}$, Faruk Metin Çomu ${ }^{3}$, Volkan Şıvgın ${ }^{4}$ Metin Alkan ${ }^{4}$, Mustafa Arslann ${ }^{4}$, Yusuf Ünal ${ }^{4}$

${ }^{1}$ Erciyes University, Faculty of Medicine, Department of Anesthesiology and Reamination, Kayseri, Turkey

${ }^{2}$ Dumlupınar University, Faculty of Medicine, Department of Physiology, Kütahya, Turkey

${ }^{3}$ Kırıkkale University, Faculty of Medicine, Department of Physiology, Kırıkkale, Turkey

${ }^{4}$ Gazi University, Faculty of Medicine, Department of Anaesthesiology and Reanimation, Ankara, Turkey

\begin{abstract}
Aim: The administration of plasma expanders is crucial for managing critically ill patients across a range of clinical conditions, including major surgery, hemorrhagic shock, and trauma. However, the effects of hydroxyethyl starch (HES) on erythrocyte aggregation remain controversial. For this reason, we aimed to investigate the effects of HES 130/0.4, performed renal insufficiency by experimentally unilateral ureteral obstruction, on erythrocyte deformability.

Materials and Methods: A total of 24 rats were divided into 4 groups; Control, HES 130/0.4, Ureter Obstruction (UO) and UO-HES130/0.4. Urethral obstruction groups were treated with ketamine anesthesia with a low abdominal incision and reached to the distal of right ureter and sutured with 2.0 mersilen then waited for 3 weeks for late term renal insufficiency. 20 $\mathrm{mL} . \mathrm{kg}^{-1}$ of HES 130/0.4 (Voluven) were infused intravenously to the HES 130/0.4 and UO-HES130/0.4 group. After 24-hour, rats were sacrificed. Deformability measurements were performed using $5 \%$ haematocrit in a phosphate-buffered saline (PBS) buffer.

Results and Discussion: Relative resistance was increased in all groups compared to the control group $(p<0.0001)$. In all groups, erythrocyte deformability index was found to be significantly higher than the control group (Group C-Group HES, p=0.023, Group C- Group UO, p<0.0001, Group C-Group UO-HES, p <0.0001). UO-HES group had significantly increased erythrocyte deformability index compared with the HES group $(p=0.031, p=0.021$, respectively). It was determined that HES 130/0.4 application did not change erythrocyte deformability in ureteral obstructed rats $(p=0.785)$.

Conclusion: The use of HES 130/0.4 has no negative effects on erythrocyte deformability in ureteral obstructed rats. We think that indications should be used correctly when using HES 130/0.4.
\end{abstract}

Key Words: Unilateral ureteral obstruction, HES 130/0.4, rat, erythrocyte deformability

Received: 11.02.2017
Accepted: 11.30 .2017

\section{ÖZET}

Amaç: Plazma genişleticilerinin uygulanması, önemli cerrahi, hemorajik şok ve travmayı içeren çeşitli klinik koşullardaki kritik hastaları yönetmek için çok önemlidir. Bununla birlikte, hidroksietil nişastanın (HES) eritrosit agregasyonu üzerindeki etkileri tartışmalıdır. Bu nedenle, deneysel tek tarafı üreteral tıkanıkık ile oluşturulan böbrek yetmezliğinde HES 130/0.4'ün eritrosit deformabilitesi üzerindeki etkilerini araştırmayı amaçladık.

Yöntem: Toplam 24 rat kontrol, HES 130/0.4, Üreter Obstrüksiyon (ÜO) ve ÜOHES 130/0.4 olmak üzere dört gruba ayrıldı. Üreteral tıkanıklık gruplarına ketamin anestezisi altında düşük abdominal insizyon yapıldı. Sağ üreterin distaline ulaşıldıktan sonra 2.0 mersilen ile bağlandı, daha sonra geç dönemde böbrek yetmezliği için 3 hafta bekledi. $20 \mathrm{~mL}^{\mathrm{kg}}{ }^{-1} \mathrm{HES}$ 130/0.4 (Voluven), HES 130/0.4 ve ÜO-HES 130/0.4 grubuna intravenöz olarak verildi. 24 saat sonra ratlar sakrifiye edildi. Deformabilite ölçümleri bir fosfat tamponlu salin (PBS) tamponu içinde\% 5 hematokrit kullanılarak gerçekleştirildi.

Bulgular: Her grupta rölatif rezistans kontrol grubuna göre arttı $(p<0.0001)$. Her grupta eritrosit deformabilite indeksi kontrol grubuna göre anlamlı derecede yüksek bulundu (Grup K-Grup HES, $\mathrm{p}=0.023$, Grup K-Grup ÜO, $p<0.0001$, Grup K-Grup ÜO-HES, $p<0.0001)$. ÜO-HES grubunda HES grubuna kıyasla eritrosit deformabilite indeksi önemli derecede arttı $(p=0.031, p=0.021$, sırasıyla). HES 130/0.4 uygulaması ile üreteral obstrüksiyon yapılmış sıçanlarda eritrosit deformabilitesinde herhangi bir değişiklik olmadığı belirlendi $(p=$ $0.785)$.

Sonuç: HES 130/0.4 kullanımı, üreteral obstrüksiyonu yapılan sıçanlarda eritrosit deformabilitesi üzerinde olumsuz bir etkiye sahip değildir. HES 130/0.4 kullanırken bu endikasyonların doğru kullanılması gerektiğini düşünüyoruz.

Anahtar Sözcükler: Tek taraflı üreteral obstrüksiyon, HES 130/0.4, rat, eritrosit deformabilitesi

Geliş Tarihi: 02.11.2017

Kabul Tarihi: 30.11.2017

Address for Correspondence / Yazışma Adresi: Mustafa Arslan, MD, Gazi University Faculty of Medicine, Department of Anesthesiology and Reanimation 06510 Ankara, Turkey E-mail:mustarslan@gmail.com

CTelif Hakkı 2018 Gazi Üniversitesi Tıp Fakültesi - Makale metnine http://medicaljournal.gazi.edu.tr/ web adresinden ulaşılabilir. (C) Copyright 2018 by Gazi University Medical Faculty - Available on-line at web site http://medicaljournal.gazi.edu.tr/ doi:http://dx.doi.org/10.12996/gmj.2018.29 


\section{INTRODUCTION}

The administration of plasma expanders is crucial for managing critically ill patients across a range of clinical conditions, including major surgery, hemorrhagic shock, and trauma (1). There is growing evidence that plasma expanders, which are often given in large volumes during fluid therapy, are associated with altered hemorheological parameters, which play an important role in modulating microcirculatory and tissue oxygenation $(2,3)$.

The decline in erythrocyte half-life in patients with renal insufficiency and therefore a cause of the anemia is the deterioration of the balance in this system. In uremic patients, decreased glucose metabolism and pentose phosphate shunt activity in erythrocytes result in increased synthesis of hydrogen peroxide and hydroxyl radicals, as well as antioxidant enzymes inhibited by uremic toxins. As a result, lipid peroxidation (LPO) in the erythrocyte membrane is accelerated, erythrocyte deformability is affected, and the splenic sequestration of erythrocytes increases and the erythrocyte side-life is shortened $(4,5)$.

In the literature, experimental and clinical studies have shown that erythrocyte deformability deteriorates in renal failure cases (6-8). Some data suggest hyperoncotic colloids and starches with a molar substitution $>0.4$ may be harmful for the kidney in patients with septic shock (9-11). Third generation hydroxyethyl starch (HES), the so-called tetrastarch (molar degree of substitution 0.4 and medium molecular weight of $130 \mathrm{kDa}$ ) with a reportedly improved safety profile, has led to renewed interest in the use of HES for volume therapy $(12,13)$.

In this study we investigated the effect of HES 130/0.4 on erythrocyte deformability of unilateral ureteral obstruction in rats.

\section{MATERIALS and METHODS}

\section{Animals and Experimental Protocol}

After obtaining approval of the Experimental Animals Ethics Committee of Gazi University, we conducted the study in the GUDAM Laboratory of Gazi University. All the experimental procedures were performed in conjunction with Guide for the Care and Use of Laboratory Animals standards. The animals were housed in a pathogen-free environment, with free access to food (until 2 $\mathrm{h}$ before the anesthetic procedure) and water and with a $12 \mathrm{~h}$ light/dark cycle for at least one week before study.

Twenty four male Wistar albino rats (225 and $275 \mathrm{gr}$ ) were randomly divided into four groups. Control (C) Group (control; $n=6)$, HES 130/0.4 (Voluven) (HES) Group (HES 130/0.4 (Voluven); n=6), Unilateral Ureteral Obstruction (UO) for 3 weeks Group (UO; $\mathrm{n}=6$ ) and Group UO-HES (UO- 20 mL. kg ${ }^{-1}$ HES 130/0.4 (Voluven); $n=6)$. Rats in the control and $\cup O$ groups received only normal saline at the same volume.

Renal failure was induced in the left ureter in four groups of rats under ketamine anesthesia with a low abdominal incision, and then the suture was placed with 2.0 mersilene and was kept there for 3 weeks for the late period. At the end of period, anesthesia was induced using $100 \mathrm{mg} \cdot \mathrm{kg}^{-1}$ ketamine

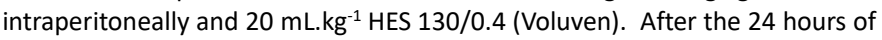
follow-up period, $100 \mathrm{mg} \cdot \mathrm{kg}^{-1}$ ketamine was administered intraperitoneally then rats (HES, UO-HES group rats) were sacrificed, after collecting blood samples from their abdominal aorta. Heparinized total blood samples were used to prepare erythrocyte packs. Deformability measurements were performed using erythrocyte suspensions with $5 \%$ haematocrit in a phosphate-buffered saline (PBS) buffer.

\section{Deformability Measurements}

Blood samples were carefully taken, and the measurement process was as fast as possible to avoid haemolysis of the erythrocytes. The collected blood was centrifuged at $1000 \mathrm{rpm}$ for $10 \mathrm{~min}$. Serum was removed, in addition to the buffy coat on the erythrocytes. An isotonic PBS buffer was added to the collapsing erythrocytes, and this was centrifuged at $1000 \mathrm{rpm}$ for $10 \mathrm{~min}$. The liquid on the upper surface was removed. Finally, pure red cell packs were obtained from the washing process, which was repeated three times. The erythrocyte packs were mixed with the PBS buffer to generate a suspension with a value of $5 \% \mathrm{Htc}$. These erythrocyte suspensions were used for the measurement of deformability. The collection and the deformability measurements of the erythrocytes were performed at $22 \circ \mathrm{C}$.

A constant-current filtrometer system was used in the measurement of the erythrocyte deformability. Samples to be measured were prepared with $10 \mathrm{ml}$ of erythrocyte suspension and PBS buffer. The flow rate was held constant at $1.5 \mathrm{ml} / \mathrm{min}$ with an infusion pump. A $28 \mathrm{~mm}$ nucleoporin polycarbonate filter with a $5 \mu \mathrm{m}$ pore diameter was preferred. Pressure changes while the erythrocytes passed through the filter were detected by a pressure transducer, and the data were transferred to the computer with the help of an MP30 data equation system (Biopac Systems Inc., Commat, USA). The calculations were performed with related computer programmes by measuring the pressure changes at various times.
Pressure calibration of the system was performed before each sample measurement. The buffer $\left(\mathrm{P}_{\mathrm{T}}\right)$ and the erythrocytes $\left(\mathrm{P}_{\mathrm{E}}\right)$ were passed through the filtration system, and the changes in pressure were measured. The relative refractory period value (Rrel) was calculated by relating the pressure value of the erythrocyte suspension to the pressure value of the buffer. An increasing Rrel in the deformability index was interpreted as adversely affecting the deformability of the erythrocytes.

\section{Statistical Analysis}

The statistical analyses were performed with the SPSS 20.0 software programme; $p<0.05$ was considered statistically significant. The findings were expressed as mean \pm standard deviation. The data were evaluated with Kruskal-Wallis variance analysis. The variables with significance were evaluated with a Bonferroni corrected Mann-Withney $U$ test.

\section{RESULTS}

Relative resistance was increased in all groups compared to the control group $(p<0.0001)$. In all groups, erythrocyte deformability index was found to be significantly higher than the control group (Group C- Group HES, $p=0.023$, Group C- Group UO, p<0.0001, Group C- Group UO-HES, p<0.0001). UO-HES group had significantly increased erythrocyte deformability index compared with the HES group ( $p=0.031, p=0.021$, respectively). It was determined that HES 130/0.4 application did not change erythrocyte deformability in ureteral obstructed rats ( $p=0.785)$ (Figure 1 ).

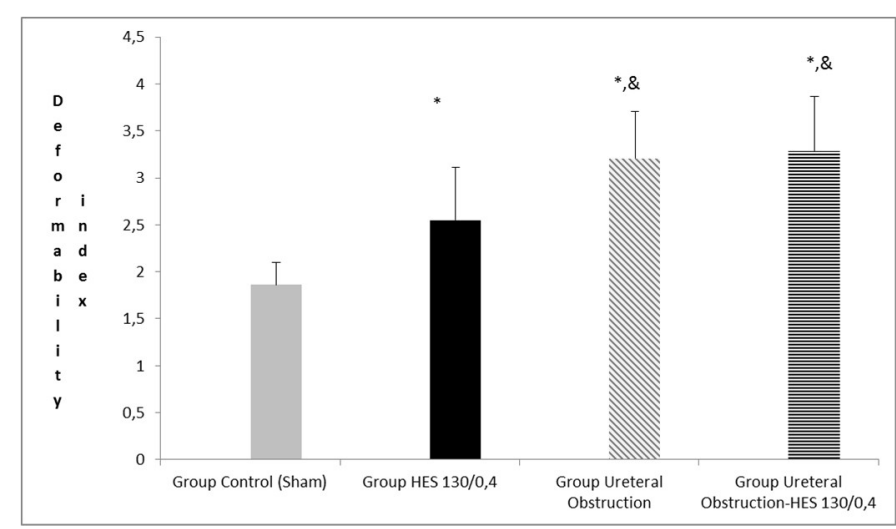

Figure 1: Erythrocyte deformabilities of each group.

Each bar represents the Mean \pm SD.

* $p<0.05$ compared to the Group Control, \& $p<0.05$ compared to the Group HES 130/0,4

\section{DISCUSSION}

Erythrocytes are fundamental elements of blood; they are responsible for vital functions such as oxygen/carbon dioxide and metabolic product exchange. Changes in erythrocyte shape and geometry generate the most important proportion of flow resistance. Erythrocyte deformability, aggregation, plasma fibrinogen and globulins have key roles to play in maintaining a sufficient flow pattern (14). It has been attributed to platelet dysfunction, abnormal platelet-vessel wall interactions and altered rheological properties of blood flow (15-19). Weed et al (20) postulated erythrocyte deformability to be a major determinant of red cell survival. This was later verified in other studies. Pekpak et al (6) demonstrated the decreased red cell deformability for the first time in a proteinuric patient group with minor renal insufficiency. The decrease in viscosity was determined by the decreased red cell deformability.

As summarised by Noris and Remuzzi, uremic bleeding depends on 1 . abnormal platelet-vessel wall interactions ( enhanced vascular PGI2 production, altered PGI2 degradation, altered ratio of Factor VIII to von Willebrand Factor), anemia (altered platelet adhesion, altered blood rheology), 3. abnormal production of Nitric Oxide and 4. platelet dysfunction (decreased platelet calcium content, reduced ADP platelet pool, reduced cAMP platelet content, reduced platelet capacity to form TxA2 in response to Platelet Activating Factor (21).

The life span of erythrocytes in the circulation seems to be related with the factors affecting the mechanical properties (cell deformability) (22). In hemodialysis patients, the breakdown of erythrocyte deformability as the result of erythrocyte membrane lipid peroxidation initiated by free radicals and splenic sequestration is reported be among the the most important factors causing a decrease in the life span of erythrocytes $(5,23-25)$. Comu et al. reported that they found the results of erythrocyte deformability $\mathrm{EI}$ (Elongation index) values, obtained under shear stress of 30 , decreased in all groups compared to the control group in their study. 
Although there was an increase in the Pentoxifylline+Quercetin group in comparison with the ATN group, they stated that it didn't show statistical significance (8). Yürekli et al. (26) reported that there was no significant difference in the El values between the Ringer and HEPP 130/0.4 groups in studying the hemorrhological effects of different prime solutions in CPB administration. Ringer and HEPE 130/0.4 solutions did not show any significant difference in terms of erythrocyte deformability in CPB administration. Two different liquids have been used by Morariu et al. (27) to provide acute isovolumic hemodilution in animal studies.

HES 200/0.5 and HES 130/0.4 solutions were compared as two separate groups. There was no significant difference in erythrocyte aggregation between the two groups. It was determined that HES 130/0.4 application did not change erythrocyte deformability in ureteral obstructed rats. The use of HES 130/0.4 has no negative effects on erythrocyte deformability in ureteral obstructed rats. We think that indications should be used correctly when using HES 130/0.4.

\section{Conflict of interest}

No conflict of interest was declared by the authors.

\section{REFERENCES}

1. Bagshaw SM, Bellomo R. The influence of volume management on outcome. Curr Opin Crit Care 2007;13:541-8.

2. Standl T, Burmeister MA, Schroeder F, Currlin E, Schulte am Esch J, Freitag M, et al. hydroxyethyl starch (HES) 130/0.4 provides larger and faster increases in tissue oxygen tension in comparison with prehemodilution values than HES $70 / 0.5$ or HES $200 / 0.5$ in volunteers undergoing acute normovolemic hemodilution. Anesth Analg 2003;96:936-43.

3. Neff TA, Fischler L, Mark M, Stocker R, Reinhart WH. The influence of two different hydroxyethyl starch solutions (6\% HES 130/0.4 and 200/0.5) on blood viscosity. Anesth Analg 2005;100:1773-80.

4. Vijoen $M$, de Oliveria AA, Milne F. Physical properties of the red blood cells in chronic renal failure. Nephron 1991; 59:271-8.

5. Rosenmund A, Binswanger $U$, Straub PW. Oxidative injury to erythrocytes, red cell rigidity and splenic hemolysis in hemodialyzed uremic patients. Ann Intern Med 1975; 82:460-5.

6. Pekpak MA, Ercan M, Konukoğlu D, Erek E. Erythrocyte membrane stiffness (or) red cell deformability, blood and plasma viscosity in proteinüric patients. Office Journal of the Turkish Nephrology, Association 1999;4:206-12,

7. Çavdar C, Temiz A, Yeniçerioğlu Y, Çalışkan S, Çelik A, Sifil A, et al. The effects of intravenous iron treatment on oxidant stress and erythrocyte deformability in hemodialysis patients. Official Journal of the Turkish Society of Nephrology 2001;10:77-82.

8. Çomu FM, Andıç MF, Edremitlioğlu M, Dikmenoğlu N. Quercetin ve Pentoksifilinin akut böbrek yetmezliğinde böbrek perfüzyonu ve eritrosit deformabilitesine etkisi. Türk Fizyolojik Bilimler Derneği 35. Ulusal Fizyoloji Kongresi, özet kitabı,2009; poster no 31, sayfa 102.

9. Schortgen F, Girou E, Deye N, Brochard L, CRYCO Study Group. The risk associated with hyperoncotic colloids in patients with shock. Intensive Care Med 2008, 34:2157-68.
10. Schortgen F, Lacherade JC, Bruneel F, Cattaneo I, Hemery F, Lemaire $\mathrm{F}$, et al. Effects of hydroxyethylstarch and gelatin on renal function in severe sepsis: a multicentre randomised study. Lancet 2001, 357:911-6.

11. Brunkhorst F, Engel C, Bloos F, Meier-Hellmann A, Ragaller M, Weiler N, et al. German Competence Network Sepsis (SepNet): Intensive insulin therapy and pentastarch resuscitation in severe sepsis. N Engl J Med 2008; 358:125-39.

12. Jungheinrich $C$, Neff TA. Pharmacokinetics of hydroxyethyl starch. Clin Pharmacokinet 2005; 44:681-99.

13. Westphal M, James MF, Kozek-Langenecker S, Stocker R, Guidet B, Van Aken $\mathrm{H}$. Hydroxyethyl starches: different products - different effects. Anesthesiology 2009; 111:187-202.

14. Singh $M$, Shin $S$. Changes in erythrocyte aggregation and deformability in diabetes mellitus: A brief review. Indian J Exp Bio 2009;47:7-15.

15. di Minno G, Martinez J, McKean M, de la Rosa J, Burke JF, Murphy S. Platelet dysfunction in uremia. Multifaceted defect partially corrected by dialysis. Am J Med 1985; 79: 552-9.

16. Castillo R, Lozano T, Escolar G, Revert L, Lopez J, Ordinas A Defective platelet adhesion on vessel subendothelium in uremic patients. Blood 1986; 68: 337-42.

17. Livio M, Marchesi E, Remuzzi G, Gotti E, Mecca G, de Gaetano G Uremic bleeding: Role of anemia and beneficial effect of red cell transfusions. Lancet 1982;11: 1013-5.

18. Małyszko J, Małyszko JS, Myśliwiec M, Buczko W. Hemostasis in chronic renal failure. Rocz Akad Med Bialymst 2005;50:126-31.

19. Goldstein DE, Little RR, Wiedmeyer HM, England JD, McKenzie EM Glycated hemoglobin: methodologies and clinical applications. Clin Chem 1986;32: B64-70.

20. Weed RI, LaCelle PL, Merrill EW. Metabolic dependence of red cell detormability. J Clin Invest 1969; 48:795-809.

21. Noris M, Remuzzi G. Uremic bleeding: Closing the circle after 30 years of controversies. Blood 1999; 94: 2559-74

22. Bull BS, Breton-Gorius J, Beutler E. Morphology of erythron. In: Williams WY, Beutler E, Erslev AJ, Lichtman MA (eds). Hematology. NewYork: Mc Graw Hill; 1991. 297-316.

23. McCay PB. Vitamin E: interactions with free radicals and ascorbate. Annu Rev Nutr 1985;5:323-40.

24. Stocks J, Offerman EL, Modell CB, Dormandy TL. The susceptibility to autoxidation of human red cell lipids in health and disease. $\mathrm{Br}$ Haematol 1972;23:713-24.

25. Ersoy A, Ersoy $C$, Dilek K, Usta $M$, Gülülü $M$, Yavuz $M$, et al. The effect of different doses of vitamin $C$ treatment on renal anemia. Uludağ Üniversitesi Tıp Fakültesi Dergisi 2002;28:5-9.

26. Yürekli İ, Uğurlu $B$. The effect of different priming solutions on the erythrocyte deformability and aggregation among cases undergoing elective coronary artery bypass surgery, Uzmanlık tezi, 2006;1-54.

27. Morariu AM, Maathuis $\mathrm{MH}$, Asgeirsdottir SA, Leuvenink HG, Boonstra PW, van Oeveren W, et al. Acute isovolemic Hemodilution Triggers Proinflammatory and Procoagulatory Endothelial Activation in Vital Organs: Role of Erythrocyte Aggregation. Microcirculation 2006;13:397-409. 